\title{
Religion, magt og kommunikation
}

\author{
Filosofiske overvejelser over religionens betydning i \\ moderniteten, set i krydsfeltet mellem Foucault og Habermas
}

\author{
Indledningsforelæsning ved
}

forsvarshandlingen den 10. december 2010

LARS ALBINUS

\begin{abstract}
ENGLISH ABSTRACT: The introductory lecture presents the main tenets of the doctoral thesis Religion, Power and Communication - Philosophical reflections on the role of religion in modernity on the grounds of the Foucault-Habermas debate. The basic idea is to approach 'religion' by taking up post-metaphysical positions in modern philosophy, not in order to condemn any religious tradition to silence, but rather to investigate what sorts of meaning potentials are more likely to be salvaged than others in a modern world. The perspective is offered by the so-called Foucault-Habermas debate which is brought to bear on the question of religion as a social phenomenon involving power and rationality. To a certain extent, Foucault and Habermas represent conflicting views on modernity. The former undertook his historical investigations from the premise that power is unavoidably present in all social relations, whereas the latter launched a theory of communication from the premise that rational agreement (Verständigung) is implicitly anticipated in any kind of communication. In trying to utilize both positions as correctives of one another, I venture to suggest a specific level of coincidence pertaining to the ethics and aesthetics of religious praxis. Conclusively, I hold that sensibilities corresponding to a religious form of life may, within the civic confines of rational commitment, point in the direction of a more open-ended attitude towards our self-understanding in the current historical situation than either fundamentalist or secularist outlooks.
\end{abstract}


DANSK RESUMÉ: Indledningsforelæsningen præsenterer hovedsynspunkterne i doktorafhandlingen Religion, magt og kommunikation. Filosofiske overvejelser over religionens betydning i moderniteten, set i krydsfeltet mellem Foucault og Habermas. Ud fra den tese, at kommunikation ikke lader sig tænke i et magttomrum, og at magt ikke (til forskel fra vold) lader sig tænke uden et mindstemål af kommunikativ indforståelse, undersøges religion som et socialt fxnomen i moderniteten. Med udgangspunkt $i$ den såkaldte Foucault-Habermas debat foretages en begrebsopbygning af 'kommunikation' og 'magt', der leder frem til et kritisk krydsfelt, hoor Foucault og Habermas kommer til at udgøre en slags korrektiver til hinanden. I forhold til religionen forsøger jeg imidlertid at udnytte et vist sammenfald i deres syn på æstetisk sensibilitet inden for rammerne af en eftermetafysisk tænkning. Jeg konkluderer, at den kommunikative rationalitet når sin grænse i religiøse og æstetiske tilværelsestolkninger, som man altid må forholde sig til på en ny tids betingelser. På den anden side må en kommunikativ fornuftsappel danne værn imod, at den sensibilitet og indignation, der bl.a. kommer til udtryk i en kritik af magt, ikke selv ender i en eskalation af magt.

Keywords: Habermas, Foucault, Rationality, Power, Philosophy of Religion, postmetaphysical thinking

For snart mange år siden blev jeg ansat som adjunkt i religionsfilosofi ved den nuværende Afdeling (daværende institut) for Religionsvidenskab. Området var til dels nyt for mig, da mit hidtidige virke havde ligget inden for studier i græsk religion og filosofi. Men skiftet bød på en oplagt mulighed for at følge et bestemt problemkompleks fra græsk oldtidskultur over i en ny sammenhæng. Snart fortonede det oprindelige fokus sig til fordel for positioner i det 20. århundredes tænkning. Alligevel forsvandt den gamle problemstilling ikke helt. Der var noget, der fortsatte med at spøge, netop fordi det $i$ en vis forstand syntes at gå igen, om end på radikalt anderledes historiske betingelser. Det, jeg havde taget med mig i bagagen, var forholdet mellem mythos og logos. Det havde beskæftiget mig som tvetydigt overgangsfænomen i min ph.d.-afhandling, og selvom jeg nu havde taget springet frem i moderniteten, ville det ikke helt slippe sit tag i mig. I forhold til den græske oldtid var jeg kommet til den opfattelse, at der på ingen måde fandt en simpel eller lineær overgang sted fra mythos til logos, men at en bestemt diskurs og praksis ikke desto mindre over tid udviklede sig på en sådan måde, at der ikke var nogen vej tilbage. Myten forsvandt ikke, men den blev netop til myte. Hvormed jeg mener, at den i forhold til logos blev til noget, den ikke tidligere havde været.

Den grundlæggende opfattelse i den her foreliggende afhandling er, at religion i dag er blevet til noget, religion ikke tidligere har været. Tiden og historien gør en forskel. Det betyder ikke, at de spørgsmål, der stiller sig til vores eksistens, ændrer sig ligeså radikalt eller hurtigt som de videnskabelige spørgsmål, vi stiller til fænomenerne tro og religion. Blot er den historiske og kulturelle sammenhæng, som den eksistentielle 
og den videnskabelige spørgehorisont indgår i, altid en ny sammenhæng. Vi har brug for et fortsat livtag med traditionen og en aldrig henslumrende viden om historien for at forstå denne sammenhæng, men historien kan aldrig give os det sidste svar. De spørgsmål, der virkelig betyder noget, her og nu, er i den forstand altid nye spørgsmål. I dette forhold, mellem det gamle og det nye, ligger min interesse for religion og den selvoverskridende fornyelse i eftermetafysisk tænkning, som også hører med til religionens historie (eller religionshistorien for nu også at udtrykke det fagterminologisk).

Der var mange sekulariseringstænkere, heriblandt Habermas, der op igennem 1970'erne og til dels endnu i 1980'erne så religion som et hendøende fænomen, men i dag, ved begyndelsen til det nye millenium, ser det anderledes ud. Religion er tilsyneladende kommet for at blive. Ud fra et filosofisk spørgsmål om gyldighed, altså i dette tilfælde religionens gyldighed, er det imidlertid ikke interessant at blive stående ved denne konstatering. Noget bliver ikke sandere af, at det breder sig, hvad historien jo har opvist talrige eksempler på. Når jeg har lagt den foreliggende afhandlings perspektiv an på betingelserne for en eftermetafysisk tænkning, skyldes det min grundlæggende overbevisning om, at oplysningen og religionskritikken i den vestlige verden har efterladt religion som noget, der ikke længere kan forblive, hvad det var, på samme måde som logos én gang for alle ændrede mythos. Men hvad forstår jeg da ved diagnosen 'eftermetafysisk'. Jeg forstår eftermetafysisk som det træk ved tænkningen, der gør, at den ikke længere kan påkalde sig et ufravigeligt holdepunkt, hvorfra den kan dømme om historien eller vores væren som mennesker. Tænkningen finder sted $i$ historien og $i$ det sociale og kulturelle fællesskab, der her og nu udgør rammen for vores væren som mennesker. Ud fra denne grundlæggende indfaldsvinkel til filosofiske overvejelser over religionens betydning forekom det mig nærliggende, men selvfølgelig også voldsomt udfordrende, at tage udgangspunkt i de to modernitetstænkere, Jürgen Habermas og Michel Foucault, der nok kan hævdes at tilslutte sig et eftermetafysisk grundsynspunkt, men som i øvrigt er eller var (for Foucault døde jo for mange år siden) uenige i næsten alt andet. Det, der i udgangspunktet forekom mig spændende, men også tæt på vanvittigt i sin prætention, var at drage nytte af begge tænkeres opfattelse af moderniteten - og herunder religionens direkte og indirekte betydning - på en måde, der ikke trivialiserede nogen af dem. Måske er det ikke lykkedes mig til fulde. Det må jeg til dels overlade til andre at dømme om; men jeg er i hvert fald gået til sagen med en dybtfølt vilje til at yde dem begge så stor retfærdighed i henseende til en forståelse og gengivelse af deres anliggende, som det var mig muligt.

Foucault og Habermas kendte selv hinanden, om end kun perifert, og havde da også indvilliget i at deltage i en amerikansk konference sammen, hvor hovedtemaet skulle være et spørgsmål om moderniteten. Mange betragtede dem nemlig dengang i 1983 som de to giganter, for ikke at sige gigantiske modsætninger, i samtidens tænkning. Desværre blev konferencens planlagte debat mellem dem aldrig til noget, da Foucault døde, kun 58 år gammel, i 1984. Med nærværende afhandling er det bl.a. hensigten at føre debatten videre på deres vegne med religion som et omdrejningspunkt, der på den ene side afspejler min dobbelte ansættelse ved teologi og religionsvidenskab her 
i Aarhus, og på den anden side har markeret sig som et tema, der siden Foucaults død er kommet til at fylde stadigt mere i den offentlige debat.

Men hvorfor er netop Foucault og Habermas valgt, kunne man spørge, når der jo gives andre moderne filosoffer, for hvem religion er selve hovedsagen i deres tænkning? Ja, simpelthen fordi jeg gerne vil kaste et andet, og i mine øjne, tiltrængt lys ind over de herskende debatter. I hvert fald har Foucault og Habermas ud fra hver deres synsvinkel peget på nogle helt grundlæggende vilkår for et moderne samfundsliv, der er af overordentlig vigtighed for en filosofisk analyse af religionens betydning og mulighed i dag.

For Foucaults vedkommende drejer det sig først og fremmest om et blik for, at meget af det, vi betragter som selvfølgeligt, også kunne have været anderledes, at historien ikke står skrevet i en nødvendig udviklings ånd, men at den tid, vi lever i, ikke desto mindre har formet os til det, vi er og ser os selv som. I den forstand udgør Foucaults med hans egne ord arkæologiske og genealogiske fremstilling af nutidens historiske forudsætninger en samtidsdiagnose. Men Foucault bliver ikke stående ved en sådan diagnose. Som sociale væsner er vi alle spundet ind i magtrelationer og diskurser, der begrænser mulighederne for, hvad vi kan gøre og sige; men der kan ikke lægges bånd på tanken selv. I tanken indgår netop den frihed, der gør, at vi på grænsen til det, vi er, kan se denne grænse i øjnene og dermed udfordre den. Af samme grund er historiens bog aldrig lukket, selvom intet gentager sig nøjagtigt, som det var. Alting er på én gang gammelt og evigt nyt. Således er religionen heller ikke et overstået kapitel, hvis man læser historien, som Foucault gør det, men snarere et arkiv af relationer, der omplacerer sig og forgrener sig på nye måder.

I henseende til Habermas kan jeg ikke se, hvorledes man kan komme uden om hans påvisning af, at historiske læreprocesser har udviklet en form for kommunikativ rationalitet, vi ikke længere kan træde bagom. I kraft af en skelnen mellem objektive, intersubjektive og subjektive gyldighedskriterier er vi på såvel et overordnet kulturelt niveau som i den konkrete samtale blevet i stand til at skelne mellem den fysiske verden, som den er, den moralske verden, som den bør være, og den subjektive verden, som vi nu engang oplever den. En sådan skelnen har ikke altid været en selvfølgelighed, men har måske i den grad realiseret sig selv, at vi er tilbøjelige til at overse dens betydning, ikke mindst dens diskursetiske betydning, dvs. en gensidig forpligtethed på ikke at blande de forskellige gyldighedsreferencer sammen. Det, der måske falder nogen for brystet, er kvalifikationen 'rationel'. Hermed mener Habermas først og fremmest, at man er parat til og i stand til at angive grunde for et udsagn af normativ eller konstativ art, hvis der stilles spørgsmål til dets gyldighed. Hermed flytter han fornuftsbegrebet ned i sproget, hvor det hører hjemme i en daglig og for så vidt før-teoretisk brug.

Når det er sagt, opstår der, for mig at se, et deficit i Habermas' teori om den kommunikative handlen, når han gør rationalitet til grundlag for en generel meningsteori. Det er oplagt rigtigt, at vi på baggrund af vores sprogkompetence forstår, hvad der i 
basal forstand kræves for rationelt og normativt at kunne tilfredsstille bestemte gyldighedsspørgsmål; men det omvendte er ikke indlysende, nemlig at vi anvender sproget ud fra et kendskab til rationelle og normative præmisser. Det Habermas hævder er, at vi slet ikke ville kunne kommunikere med hinanden, hvis vi ikke implicit havde en forventning om, at vi uden tvang kunne komme til enighed med hinanden. Det er slet og ret den forventning, der ligger indlejret i sproget som kommunikationsmiddel. Dette ser jeg ingen grund til at betvivle; men det er ikke ensbetydende med, at magtrelationer altid er sekundære eller parasitære i forhold til den kommunikative indforståelse. Her taler jeg ikke om magt i Hannah Arendts forstand som det at kunne handle i fællesskab, men om magt som asymmetri, som det ulige forhold, at mulig tvang fra den ene parts side indvirker på den andens parts handlen. Som forudsætning for at tale om magt i denne forstand, ja, for overhovedet at kunne kritisere den, må man ifølge Habermas indtage en position, der ikke selv er underkastet magtrelationer, og derfor er magt som realitet og som teoretisk genstand altid noget sekundært i forhold til en rationel indforståelse. Ifølge Foucault er dette udtryk for en utopi, en illusion om, at kommunikation i praksis kan finde sted i et magtfrit rum.

Forskellen mellem Habermas og Foucault i den henseende er, at Habermas stiller et spørgsmål til, hvad der må være opfyldt i den kommunikative interaktion, for at en fri, jævnbyrdig og rationel argumentation kan finde sted, hvilket samtidig svarer til de læreprocesser, der kan konstateres ved uddifferentieringen af modernitetens tre gyldighedskriterier. Foucault derimod spørger ikke til, hvad der i principiel forstand må være opfyldt, eller hvorledes vi i praksis kan styrke en bestemt form for rationalitet - han spørger historisk til, om den måde, hvorpå vi er formet som rationelt ansvarlige subjekter, kan adskilles fra en konkret praksis, der blandt så meget andet kan ses som en magtudøvelse. Hans svar er, at magten følger med, også dér, hvor den forekommer svagest.

Til gengæld får Foucault et problem med at forklare magtbegrebets 'teoretiske' ydelse. Hvis den konkrete demaskering af magt (som f.eks. i forhold til en rationaliserende retfærdiggørelse af en given praksis) blot appellerer til en anden konstellation af sandhed og magt, er der slet ikke tale om en demaskering, men om en af magt relativeret beskrivelse af magt. Hvis alt er magt, bliver magtbegrebet såvel kritisk som deskriptivt redundant. Men Foucault hævder da heller ikke, at alt er magt; blot at magtrelationer er allestedsnærværende og derfor fordrer en kritisk agtpågivenhed. Spørgsmålet bliver imidlertid, hvad Foucault appellerer til i sine historiske analyser, hvis han ikke blot taler ind i en her og nu skjult konstellation af magt og viden. Han må, så vidt jeg kan se, underforstået eller ej, appellere til muligheden for en rationel indforståelse. Problemet er, at denne forudsætning optræder underbestemt i hans forfatterskab. Selv ville han formentlig sige noget i retning af, at han af respekt for sin læser og i overensstemmelse med en magtminimerende grundholdning overlader en kritisk stillingtagen til læseren selv; men det ændrer ikke på, at billedet af diskursernes og magtrelationernes eget spil let kommer til at overskygge det grundlag af gyldig- 
hedskriterier, der trods alt må være til stede, for at vi kan tage stilling med andet og mere end fornemmelser og følelser.

Som det måske allerede er fremgået, har det således været min hensigt at bringe Foucault og Habermas i spil over for hinanden med henblik på at udnytte det øjenåbnende i deres indfaldsvinkler som korrektiver til hinanden, ikke forstået på den måde, at jeg forestiller mig en ophævelse af deres positioner til en syntetisk inkorporation af fornuft og magt i en og samme teori, men som et udtryk for, at kommunikationsteorien lider under et deficit i henseende til at bestemme den konkrete kommunikative praksis' magtinfiltration, og at magtanalytikken (for en egentlig teori er der ikke tale om hos Foucault) lider under, at kriterierne for de rationalitetsstandarder, der underforstået appelleres til, ikke gøres eksplicit gældende.

Religion kommer nu ind i billedet som den sag, der står til diskussion ud fra denne dobbelte indfaldsvinkel, og min hovedtese kan formuleres som en hævdelse af, at netop spændingsfeltet mellem magtrelationer og rationel indforståelse kaster et særligt lys over religionens aktuelle betydning. Det kan også formuleres på en anden måde: Selvom en religiøs overleveringstradition næppe kan udtømmes i praksis eller udsagn, for hvilke der gives rationelle argumenter, så har en grundlæggende bevidsthed om eksistensens endelighed og fornuftens ansvarlighed dog indfundet sig på en måde, der gør, at vi ikke længere med samme ret og styrke som tidligere kan opretholde troen på metafysiske referencer og blinde autoriteter. Historien kan ikke rulles tilbage igen, heller ikke af dem, der appellerer til en ortodoks revitalisering af traditionen, for de undsiger på ingen måde en moderne akademisk diskurs som det redskab, der må tages i brug i forsvaret for det førmoderne. Enhver revurdering af mythos har allerede gennemført overgangen til logos. Hvis oplysning består i, som Kant formulerede det, at vi vover at tage skridtet ud af vores selvforskyldte umyndighed, så betyder det, at vi har givet afkald på en autoritet udefra. Vi må selv tage ansvar for det liv, vi er kastet ind i. Som Habermas ser det, er dette en erkendelse, som den kristne tradition i en vestlig kontekst har udviklet, ikke i modsætning til sig selv, men i form af en kritisk selvtilegnelse, der, om man så må sige, har sat mennesket frit i Guds navn. For så vidt som dette gøres gældende med en prætention om universel gyldighed, involverer det sig i praksis med magt, både i forhold til den enkeltes eventuelle troshorisont og i forhold til samfundsgrupper af anderledes tænkende. I Habermas' optik er det imidlertid selvgendrivende at tale om magt i denne forbindelse, fordi netop den kommunikative diskurs alene fordrer rent formale, ikke indholdsmæssige, betingelser for en rationel dialog, og som sådan er kommunikativ rationalitet det eneste reale modbegreb til magt, for ellers ville alt og intet kunne kaldes for magt. I Foucaults optik ville en sådan indvending intet ændre ved, at vi i praksis konstant involverer os i magtrelationer, ikke sådan at forstå, at vi hver især som personer er magtens subjekt, men på den måde, at selv tilsyneladende symmetriske kriterier for opnåelsen af enighed i praksis omsættes til asymmetriske vilkår. For den person, for hvem sammenhængen mellem form og indhold i en given kommunikativ handlen er uadskilleligt indlejret i en religiøs optik, vil opleve den rationelle dialogs rent formale betingelser som en magtbaseret 
fordring, der uundgåeligt vil få indholdsmæssige konsekvenser. Magten sniger sig ind, selv dér hvor den forekommer svagest. Til gengæld er der forskel på, om magtrelationerne selv underkastes vilkår, der forhindrer dem i at eskalere i asymmetri, eller om de tvinges mod deres eget nulpunkt i form af en herredømmefri dialog, hvis deltagere alene accepterer det bedre, men aldrig sidste, argument. Det jeg hævder er, at begreber om magt og fornuft kan spille sammen uden at ophæve hinanden, og at dette samspil kaster lys over religion i moderniteten. Hvorfor det? Jo, bl.a. fordi den Gud, der i kristendommen har overladt magten til menneskenes egen forvaltning, deler et anliggende med fornuftens kommunikative ansvarlighed. Og samtidig peger religionen tilbage på et meningsgivende sprog for de tilværelsesvilkår - eller det niveau af magt - der unddrager sig fornuftens beherskelse. I forhold til den menneskelige værens uafgjorte og formbare karakter forbliver religion en tolkningsmulighed, der ikke synes at ville slippe sit tag i os.

Habermas hævder da heller ikke, at en religiøs overleveringssammenhæng kan erstattes af eller udtømmende oversættes til en eftermetafysisk fornuftsdiskurs. Faktisk har han gennem de seneste år, hvor Foucault af gode grunde ikke har kunnet deltage i debatten, tilkendegivet en åbenhed for, at et religiøst sprog kan udvise en sensibilitet over for en livssituation, som fornuftens kriterier ikke er gearet til at indfange. Således taler han også som mange andre om, at vi lever i et postsekulært samfund. Det betyder imidlertid ikke, at han giver køb på nødvendigheden af at fastholde sekulære kriterier for opretholdelsen af et demokratisk samfund, herunder sikringen af religionsfrihed, men derimod at han indser det umulige og uønskede i at afpresse folk en stillingtagen, der går imod deres religiøse selvforståelse. Dog må de som borgere under en demokratisk forfatning indstille sig på, at de i forhold til politiske beslutningsprocesser må tilsidesætte kulturelle særopfattelser eller særregler, som strider imod de almene borgerlige rettigheder. Derfor er det vigtigt for Habermas, at det er intersubjektivt begrundede normer og ikke blot værdier, forstået som særkulturelle præferencer, der er bestemmende for en moralsk og politisk horisont. Hvis vi erstatter en fælles argumentationsforpligtelse med en værdikamp, sætter vi selve den kommunikative rationalitets modernitetsgevinst over styr til fordel for følelsesbindinger, der ikke alene åbner for en sensibel tilværelsesforståelse, men også for fjendebilleder og regressive energier. Ville Foucault kunne erklære sig enig? Ikke ubetinget. Hans fascination af den islamiske opstand mod den amerikansk støttede shah tilbage i 1978 vidner i hvert fald om noget andet. Han støttede ikke eksplicit iranernes opstand, men han afviste, at man kunne anvende vestlige standarder i forståelsen af det, der var på færde her som en særlig politisk spiritualitet. Foucault blev selvfølgelig skuffet, da mullaherne med Khomeini i spidsen først var kommet til magten. Nu er det let at være bagklog, men måske var Foucault faktisk lidt for let at forføre. Habermas, der i efterkrigstidens Vesttyskland så det som filosofiens vigtigste opgave at sikre sig imod regressive kræfter, har måske udvist en større modstandskraft, som det er værd at lytte til. For Habermas kan religiøse udsagn ikke længere tilfredsstille normative gyldighedskriterier, med mindre de kan omsættes til et moralsk talehandlingstilbud, der kan anerkendes 
rationelt af alle involverede parter. Til gengæld hævder han netop ikke, at en moralsk fornuftsdimension kan definere et meningsfuldt livsindhold, og af samme grund skelner han mellem en moralsk diskurs på intersubjektivitetens niveau og en etisk-eksistentiel betydningssammenhæng på subjektivitetens niveau. Det er her, religion hører hjemme, men det gør også kunst og andre betydningsområder, der ikke uden videre kan oversættes til en fælles forståelseshorisont. På dette område kan Habermas og Foucault til en vis grad mødes, nemlig for så vidt som også Foucault, specielt i den sidste del af sit forfatterskab, beskæftiger sig med det, han kalder for eksistensens æstetik, og som med udgangspunkt hos de gamle grækere undersøger de historiske muligheder for, hvorledes det menneskelige subjekt kan forholde sig til selv uden at være underkastet en bestemt moralkodeks. Foucault udfolder her den tanke, at mennesket i dag atter har en mulighed for (med et begreb hentet fra Oscar Wilde) 'at forme sit liv som et kunstværk for sig selv', og den etiske dimension i dette selvforhold består $i$ at forholde sig til sig selv i forholdet til andre. Når Foucault i den forbindelse ikke taler om moral, skyldes det, at han i vid udstrækning betragter moral som 'bedrevidenhed' på vegne af andre eller i mere generel forstand som fordringen om en samvittighedsfuld selviagttagelse, der i hovedsagen kan føres tilbage til kristendommens historiske installation af pastorale magtrelationer.

Foucault og Habermas er altså enige om at tage udgangspunkt $\mathrm{i}$ individets ansvar for sit eget liv, men med den forskel, at Foucault tænker op imod traditionen ud fra det, han selv kalder for en spirituel transformationsvillighed, mens Habermas betragter individet som et væsen, der er indsocialiseret i en bestemt sammenhæng, der hele tiden kræver en kritisk selvtilegnelse. Foucault tænker op imod det, historien har formet os som; Habermas tænker med det, historien har formet os som. Måske er denne spænding det virkeligt konstruktive i modstillingen mellem de to og fremviser netop et prisme for forholdet mellem det gamle og det altid nye. At religion ikke længere kan være det, religionen var engang, betyder bl.a., at meget af det, der kom til udtryk inden for religionens dogmatiske rammer, har forgrenet sig i andre sammenhænge, bl.a. kunsten. Det æstetiske i overordnet forstand udgør netop et felt, hvor en samtale, eller kritisk dialog, kan bringes i stand mellem Foucault og Habermas. Religionens uendelighedsdimension har indlejret sig i en æstetisk horisont, hvor den enkelte i et reflekteret selvforhold må tage ansvar for sin egen livshistorie. Det uendelige ligger ikke kun, som i troens optik, i en magt uden for verden, men også i, at verden åbner sig på ny, indefra, om man så må sige, såvel gennem den absolutte forpligtelse, der kan ligge i en kommunikativ indforståethed, som gennem den livsdybde, der gennemtrænger den enkeltes uforvekslelige livshistorie i forholdet til andre.

Hverken den rationelle eller den æstetiske betydningshorisont kan som sådan træde i stedet for religion. Dog er den filosofisk mest reflekterede måde at møde tidens udfordring på ikke at gribe tilbage til et nostalgisk traditionsbegreb, men derimod at forholde sig til det, der allerede er sagt 'til os', på den måde, at vi hele tiden reformu- 
lerer det i forhold til hinanden og i forhold til en værenssammenhæng, der aldrig blot er foregrebet, men som til enhver tid, og dvs. her og nu, også er en helt ny tid.

Lars Albinus, lektor, dr.theol Afdeling for Religionsvidenskab, Arabisk og Islamstudier Faculty of Arts, Aarhus Universitet 